\title{
The PA G gene product, a stress-induced protein with antioxidant properties, is an Abl SH3-binding protein and a physiological inhibitor of c-Abl tyrosine kinase activity
}

\author{
Shih-Te Wen and Richard A. Van Etten ${ }^{1}$ \\ Center for Blood Research, Department of Genetics, Harvard M edical School, Boston, M assachusetts 02115 USA
}

\begin{abstract}
Biochemical and genetic evidence suggests that the tyrosine kinase activity of c-Abl is tightly regulated in vivo by a cellular factor binding to the Src homology 3 (SH3) domain of Abl. We used the yeast two-hybrid system to identify a gene, PA G, whose protein product (Pag) interacts specifically with the Abl SH3 domain. Pag also known as macrophage 23-kD stress protein (MSP23), is a member of a novel family of proteins with antioxidant activity implicated in the cellular response to oxidative stress and in control of cell proliferation and differentiation. In a co-expression assay, Pag associates with c-Abl in vivo and inhibits tyrosine phosphorylation induced by overexpression of c-Abl. Inhibition requires the Abl SH3 and kinase domains and is not observed with other Abl SH3-binding proteins. Expression of Pag also inhibits the in vitro kinase activity of c-Abl, but not SH3-mutated Abl or v-Abl. When transfected in NIH-3T3 cells, Pag is localized to nucleus and cytoplasm and rescues the cytostatic effect induced by c-Abl. These observations suggest Pag is a physiological inhibitor of c-Abl in vivo.
\end{abstract}

[Key Words: c-Abl; Bcr-Abl; Philadel phia chromosome; two-hybrid system; SH3 binding protein]

Received June 4, 1997; revised version accepted July 31, 1997.

The c-abl proto-oncogene encodes a nonreceptor tyrosine kinase similar to the Src family of tyrosine kinases. It was originally identified as the cellular homolog of the transforming gene of Abelson murine leukemia virus (Goff et al. 1980; Wang et al. 1984). Structurally, the amino-terminal half of c-Abl is similar to many Src family kinases, consisting of a variable region followed by an SH 3 domain, a Src homology 2 (SH2) domain, then the catalytic kinase or Src homology 1 (SH1) domain. Unique to the c-A bl tyrosine kinase, however, is a large carboxy terminus that is encoded by a single large exon. In this segment of $>600$ amino acids, there are three nuclear localization signals (Van Etten et al. 1989; Wen et al. 1996), several proline-rich sequences capable of binding to $\mathrm{SH} 3$-containing proteins such as $\mathrm{Crk}$ (Feller et al. 1994; Ren et al. 1994), a DNA-binding domain (Kipreos and Wang 1992), an actin-binding domain (McWhirter and Wang 1993; Van Etten et al. 1994), and sites for phosphorylation by protein kinase C (Pendergast et al. 1987) and cdc-2 kinase (Kipreos and Wang 1990). The physiol ogical role of c-Abl is unknown. The ubiqui-

${ }^{1}$ Corresponding author.

E-MAIL vanett@warren.med.harvard.edu; FAX (617) 278-3030. tous expression pattern of c-A bl and its complex structure suggest that this tyrosine kinase may have a fundamental function in cell physiology. This is supported by the fact that mice with homozygous inactivation of the c-abl locus display a strong tendency for runted growth and neonatal death (Schwartzberg et al. 1991; Tybulewicz et al. 1991). Recently, it has been found that the nuclear form of c-A bl is an inhibitor of cell proliferation (Sawyers et al. 1994; Wen et al. 1996), and that c-A bl kinase activity can be activated by DNA damage (Kharbanda et al. 1995; Liu et al. 1996; Y uan et al. 1996) and is required for activation of the Jun kinase (JNK)/stressactivated protein kinase (SAPK) pathway, suggesting a role for c-Abl in the stress response to genotoxic insult.

In v-Abl- and Bcr/Abl-transformed cells, there are increased levels of phosphotyrosine-containing proteins (Sefton et al. 1981), and one of the most prominent phosphotyrosinated species is the Abl protein itself (Witte et al. 1981; Pendergast et al. 1993). Overexpression of c-A bl at levels 5- to 10-fold over the endogenous C-A bl, however, does not result in cell transformation or elevated tyrosine phosphorylation in cells, suggesting that the cAbl tyrosine kinase activity is tightly regulated in vivo (Franz et al. 1989; Jackson and Baltimore 1989). In contrast, phosphotyrosine can be detected on c-Abl and 
many other cellular proteins after overexpression of cAbl 100-fold or more in Cos cells or Sf9 insect cells (Pendergast et al. 1991a), suggesting that a cell lular factor that regulates $\mathrm{Abl}$ tyrosine kinase activity may be titrated out. Abl proteins with del etion or point mutations of the SH3 domain induce transformation and increase phosphotyrosine levels in a variety of cell types (Franz et al. 1989; Jackson and Baltimore 1989; Van Etten et al. 1995), suggesting that the $\mathrm{SH} 3$ domain suppresses the intrinsic transforming ability of c-Abl. The negative regulatory effect of the SH3 domain, however, does not appear to act in cis, because SH3-del eted A bl and c-Abl have identical tyrosine kinase activity when assayed in vitro (Franz et al. 1989; Mayer and Baltimore 1994; Van Etten et al. 1995). Taken together, these observations suggest that c-Abl tyrosine kinase activity is reversi bly inhibited in vivo by a cellular factor that interacts with the $\mathrm{SH} 3$ domain, such that mutations in SH3 lead to loss of inhibition of the Abl kinase by this factor, al lowing expression of the latent kinase activity of Abl.

In this study, we have identified an Abl SH3-binding protein which, when overexpressed, can inhibit Abl kinase activity both in vivo and in vitro. This inhibitor associates with $\mathrm{Abl}$ through both the $\mathrm{SH} 3$ and the kinase (SH1) domains. Further, it can rescue the cytostatic effect induced by c-Abl. This protein, therefore, has many of the properties expected of a physiological inhibitor of c-A bl. Interestingly, this putative Abl inhibitor has been identified previously as a serum- and oxidative stressinduced protein with antioxidant and cell cycle regulatory properties.

\section{Results}

\section{Identification of $\mathrm{Abl} \mathrm{SH} 3$ domain binding proteins}

To isolate candi date $A b l$ inhibitors that interact with the Abl SH 3 domain, we screened a HeLa cell cDN A library with the yeast two-hybrid system (Chien et al. 1991; Gyuris et al. 1993) with the murine Abl SH 3 domain as a fusion bait. From a total of 10 million library transformants, we identified several positive clones that showed gal actose-dependent growth on $\mathrm{Leu}^{-}$selective medium and gal actose-dependent $\beta$-gal actosidase activity. We rescreened these clones by use of an $\mathrm{SH} 3$ domain point mutant P131L as the bait in the yeast interaction trap. The P131L mutation, which substitutes leucine for a highly conserved proline residue at the hydrophobicbinding surface of $\mathrm{SH} 3$, blocks binding of the $\mathrm{Abl} \mathrm{SH} 3$ domain to proline-rich ligands and potently activates transformation by c-A bl in vivo (Van Etten et al. 1995). Only those clones that had absent or reduced interaction with the P131L SH3 domain were analyzed further by DNA sequencing. Some of these remaining clones had prolinerich PXXP sequences, the canonical motif known to bind SH3 domains (Cicchetti et al. 1992; Ren et al. 1993), although others did not.

The most abundant clone, comprising nearly onequarter of the final population, was recovered as two independent cDNA clones, one 650 nucleotides, the other 600 nucleotides. Both sequences were $100 \%$ identical to a previously cloned cDN A called human proliferation-associated gene (PAG) (Prosperi et al. 1993) (Fig. 1). The PAG gene is constitutively expressed in most human cells and is induced to higher levels on serum stimulation. The PAG CDNA codes for a 22-kD protein that is devoid of any consensus motif, is not particularly proline-rich, and lacks PXXP motifs. The murine homolog of Pag has been cloned as a macrophage protein (M SP23) induced by oxidative stress (Ishii et al. 1993) and as a protein (OSF-3) up-regulated during differentiation of osteoblasts (Kawai et al. 1994). Pag/ M SP23 al so shows significant homology to cell-surface antigens from Entamoeba histolytica and Helicobacter pylori, and to bacterial and yeast peroxiredoxin proteins (Chae et al. 1994a).

\section{Pag interacts specifically with the $\mathrm{Abl} \mathrm{SH} 3$ domain}

To test the interaction specificity between Pag and the Abl SH3 domain, we repeated the yeast two-hybrid interaction with $\mathrm{SH} 3$ domains from C-Src, Grb-2, and the phosphatidylinositol 3-kinase (PI3K) p85 subunit. N one of these $\mathrm{SH} 3$ domains showed any interaction with Pag (Fig. 2). Similarly, other domains of c-Abl including the carboxyl terminus and the kinase ( $\mathrm{SH} 1$ ) domain, as well as several unrelated protein baits (Bicoid, cdc2 and $\beta_{2^{-}}$ integrin; data not shown) did not interact with Pag in the yeast system.

Pag inhibits the tyrosine kinase activity of c-Abl in vivo

High-level expression of c-Abl by transient transfection induces tyrosine phosphorylation of Abl and other cellular proteins, possibly because a cellular inhibitor is present in limiting amounts (Pendergast et al. 1991a; Van Etten et al. 1995). We reasoned that an Abl SH3binding protein that was a physiological inhibitor of c-

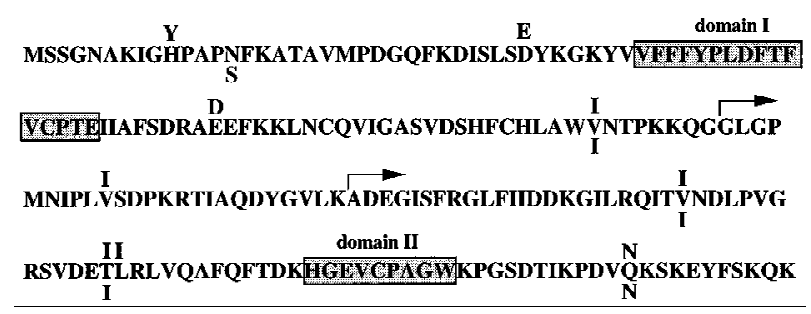

Figure 1. Amino acid sequence of Pag and its murine and rat homologs. The sequence of human Pag (Prosperi et al. 1993) is given according to the single letter amino acid code. Letters above denote substitutions present in the murine homolog MSP23 (Ishii et al. 1993); letters bel ow indicate substitutions in the rat homolog (HBP23) (Iwahara et al. 1995). Domains I and II are regions containing cysteine residues that are conserved among the family of peroxide reductases (Chae et al. 1994a). The arrows indicate the locations of the point of fusion of the two CDNAs recovered in the yeast two-hybrid screen with the B42 transactivation domain. 


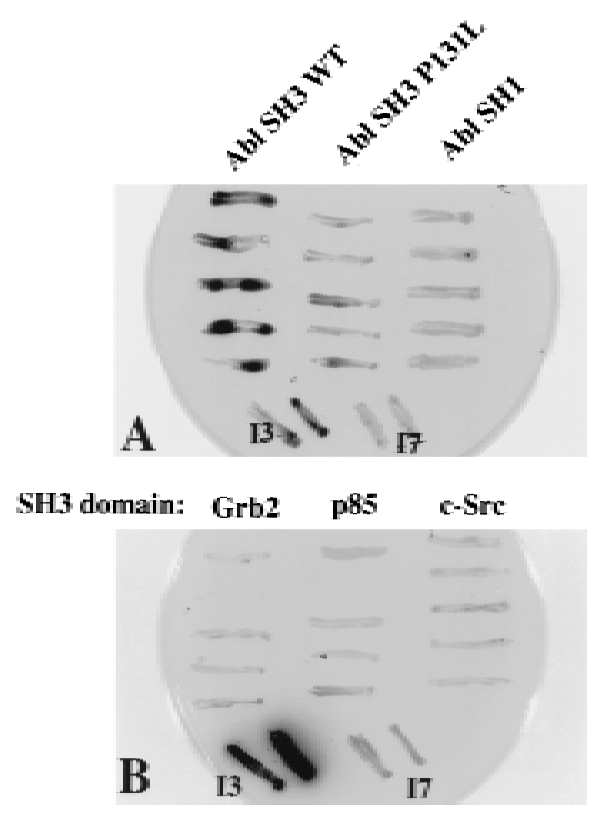

Figure 2. Pag interacts specifically with the Abl SH3 domain in the yeast two-hybrid system. Y east strain EGY 48, containing Pag fused to the B42 transactivation domain, was transformed with different LexA baits and $\beta$-galactosidase activity detected on gal actose $X$-gal plates as blue color (dark). 13 and 17 are positive controls (Gyuris et al. 1993) with 13 demonstrating strong transactivation and 17 weaker transactivation. (A) Pag interacts with the $\mathrm{Abl} \mathrm{SH} 3$ domain, but not with a mutant $\mathrm{SH} 3$ domain containing an activating point mutation (P131L) or the Abl kinase domain (SH1). (B) Pag fails to interact with $\mathrm{SH} 3$ domains from Grb2, PI3K p85 subunit, and c-Src.

Abl might suppress tyrosine phosphorylation when coexpressed with Abl. Accordingly, we tested clones identified in thetwo-hybrid screen for the ability to reduce or abrogate tyrosine phosphorylation induced by $\mathrm{c}-\mathrm{A} \mathrm{bl}$ in this assay. Coexpression of Pag in the sense, but not the antisense, orientation significantly suppressed the tyrosine phosphorylation induced by c-Abl, but not that induced by $\mathrm{A}$ bl proteins with $\mathrm{SH} 3$ deletion $(\triangle \mathrm{SH} 3$ ) (Fig. $3 \mathrm{~A}$ ) or the activating SH3 point mutation (P131L) (data not shown). Interestingly, Pag was an excel lent substrate for $\mathrm{SH} 3$-mutated $\mathrm{Abl}$. N one of the other clones we isolated in the two-hybrid screen had such an inhibitory effect (data not shown). Inhibition of Abl tyrosine kinase activity by Pag was sensitive to the level of expression of Pag (Fig. 3B).

We also tested several other known Abl SH3-binding proteins including Mena, the mouse homolog of Drosophila Ena (Gertler et al. 1996), and Abi-1 and Abi-2, SH3-containing proteins identified by two-hybrid screens (Dai and Pendergast 1995; Shi et al. 1995). When coexpressed with c-Abl, these SH3-binding proteins failed to inhibit tyrosine phosphorylation (Fig. 3C) but were instead good substrates for $\mathrm{Abl}$ kinase activity. $\mathrm{Rb}$ $\mathrm{SE}$, the $\mathrm{C}$ pocket of the retinoblastoma gene product, has been shown to bind to the ATP-binding domain of nuclear Abl and inhibits its kinase activity in a cell- cycle-specific manner (Welch and Wang 1995). However, the $\mathrm{Rb}$ SE protein also failed to inhibit Abl-induced tyrosine phosphorylation in this hyperexpression assay (Fig. 3C). These observations show that inhibition of C$\mathrm{Abl}$ kinase activity is a unique property of Pag.

In some experiments, coexpression of Pag appeared to slightly decrease the level of c-A bl protein in transfected cells (Fig. 3C, middle panel). This effect was never observed with SH3-mutated Abl or with expression of Pag in the antisense orientation. Because of the difficulty in comparing the relative expression of proteins by Western blotting, we labeled transfected cells with [ $\left.{ }^{35} \mathrm{~S}\right]$ methionine and found a $20 \%-25 \%$ decrease in the level of c-Abl protein in cells cotransfected with Pag (Fig. 3C, top), suggesting that part of the reduction in phosphotyrosine mediated by Pag may be caused by decreased Abl expression. Increasing the level of Pag, however, resulted in further decreases in phosphotyrosine without affecting the expression of C-A bl (Fig. 2B), and coexpression of Pag inhibited the in vitro kinase activity of c-Abl (see below), showing that Pag also has a direct inhibitory effect on c-Abl kinase activity.

Inhibition of tyrosine phosphorylation might also be caused by some nonspecific effect of overexpression of Pag such as activation of a tyrosine phosphatase. To address this issue, we tested the effect of Pag on a closely related nonreceptor tyrosine kinase, c-Src, in the hyperexpression assay. Pag had no effect on phosphotyrosine levels induced by either overexpressed c-Src (Fig. 3D) or the c-Src mutant Y 527F (data not shown). We al so tested the effect of Pag on an Abl-SrcTK chimera in which the kinase domain from c-Src had been substituted for the Abl kinase domain, and could not detect any inhibition of the tyrosine phosphorylation induced by this chimera (Fig. 3D). These observations suggest that inhibition of tyrosine phosphorylation by Pag is specific to $A b l$ and requires the $\mathrm{Abl} \mathrm{SH} 3$ and kinase domains.

\section{Pag and c-Abl associate in vivo}

To investigate the in vivo association between Pag and $\mathrm{c}-\mathrm{Abl}$, the PAG gene product was epitope-tagged with the nine amino acid epitope from the influenza hemagglutinin (HA) protein recognized by monoclonal antibody 12CA5 (Wilson et al. 1984), and coexpressed with Abl in $293 \mathrm{~T}$ cells. Pag coimmunoprecipitated with c-Abl (Fig. 4A), showing an in vivo association between Pag and $A$ bl. Surprisingly, $\mathrm{C} 4 \Delta \mathrm{SH} 3$, the SH 3 del etion mutant of $A b l$, also coimmunopreci pitated with Pag, raising the possibility that the interaction between Pag and $A b l$ in vivo may involve more than just the $\mathrm{SH} 3$ domain al one. To map a second interacting site, a series of $\mathrm{Abl}$ deletion mutant proteins with or without the $\mathrm{SH} 3$ domain were coexpressed with Pag. The $c 4 \Delta \mathrm{SH} 3 \Delta \mathrm{Bcl}$ protein, which is missing most of the carboxyl terminus, coimmunoprecipitated with Pag (Fig. 4B), indicating the carboxyl terminus of $A b l$ is dispensable for this interaction. However, Abl proteins with deletion of the entire kinase domain $(\triangle \mathrm{SH} 1)$ or just the ATP-binding lobe $(\triangle \mathrm{ATP})$ showed a drastic decrease in coimmunoprecipitation, 


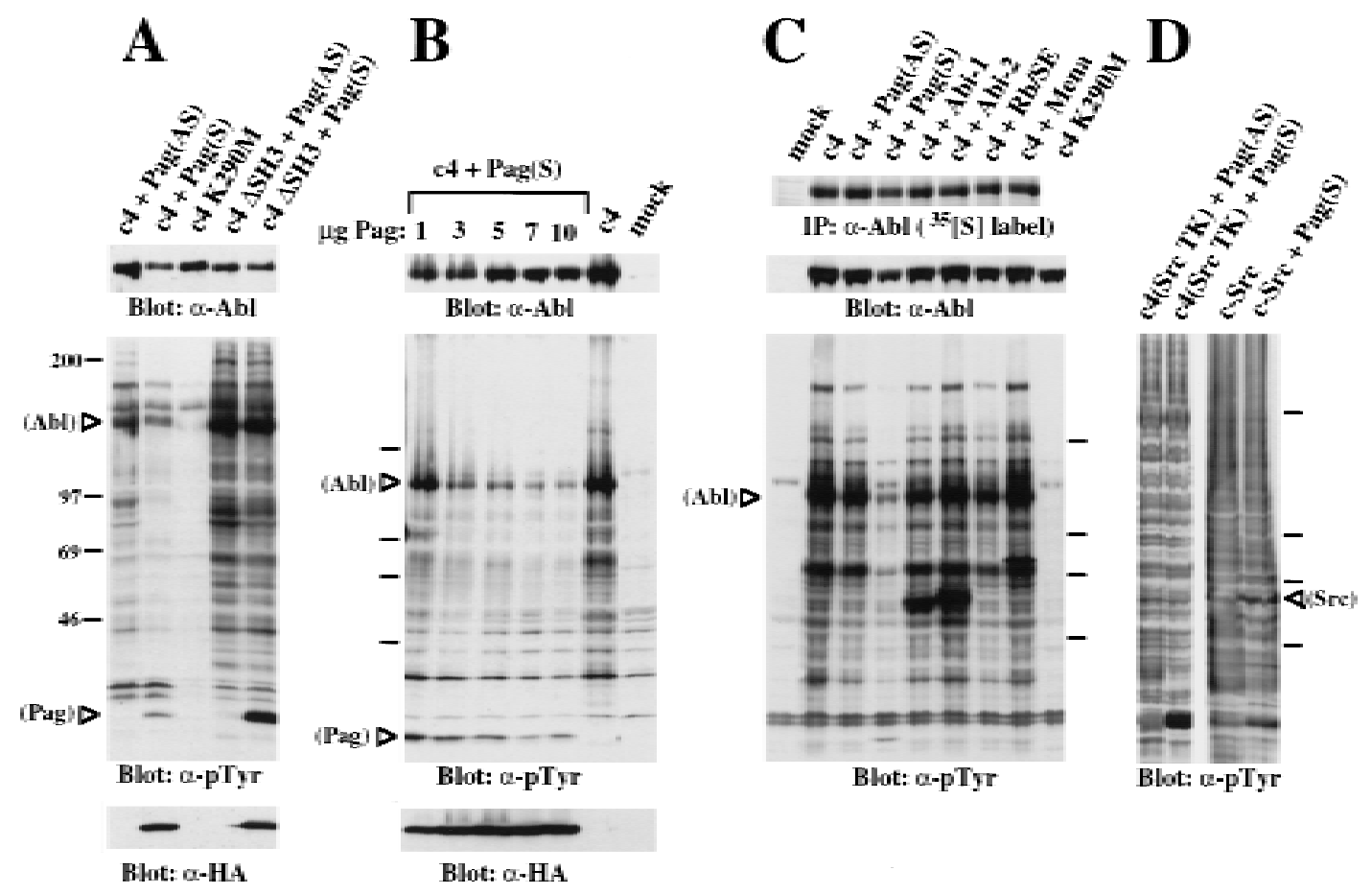

Figure 3. Pag inhibits the tyrosine phosphorylation induced by c-Abl in vivo. The indicated proteins were expressed by transient transfection of 293T cells, and lysates containing equal amounts of protein compared for their phosphotyrosine levels by immunoblotting with anti-phosphotyrosine antibody $4 \mathrm{G} 10$. Where indicated, the blot was then stripped and reprobed with anti-A bl mAb 8E9 to detect c-A bl or anti-hemagglutinin mAb 12CA5 to detect epitope-tagged Pag. (A) Pag inhibits c-A bl but not SH3-del eted Abl. Pag, in either sense (S) or antisense (AS) orientation, was cotransfected with wild-type c-A bl (c4) or SH3-del eted Abl into 293T cells. (B) Inhibition of Abl by Pag is dose-dependent. 293T cells were cotransfected with 5 ug of c-Abl (c4) and increasing amounts (1, 3, 5, 7, and $10 \mu \mathrm{g}$ ) of Pag. (C) Other SH3-binding proteins and pRb fail to inhibit c-Abl. 293T cells were cotransfected with Abl and different $\mathrm{Abl} \mathrm{SH} 3$ domain binding proteins (Pag, M ena, A bi-1, Abi-2) or Rb SE, the C pocket of retinoblastoma gene product. Expression of these proteins at levels similar to that of Pag was confirmed by immunoblotting with anti-M ena or anti-epitope antibodies (data not shown). (D) Inhibition of Abl by Pag requires the Abl kinase domain. 293T cells were cotransfected with Pag in either sense (S) or antisense (AS) orientation and with the Abl c4-SrcTK chimera or c-Src.

suggesting that the ATP-binding lobe of the Abl kinase domain may be directly or indirectly involved in the interaction of Pag and Abl. Tyrosine phosphorylation of $A b l$ is not required for the Pag-A bl interaction because the mutant c4 $\Delta \mathrm{Bgl}-\mathrm{Bcl}$, which lacks the carboxy-terminal catalytic lobe of the kinase domain and is not detectably tyrosine phosphorylated upon overexpression (data not shown), retained significant co-immunoprecipitation with Pag (Fig. 4B).

\section{Pag is localized to nucleus and cytoplasm}

To determine the subcellular localization of Pag, epitope-tagged Pag was coexpressed with c-A bl in both 293T and N IH-3T 3 cells. Double immunofluorescence staining with anti-epitope monoclonal antibody (mAb) 12CA 5 and anti-Abl antibodies was performed. Pag was expressed both in the nucleus and the cytoplasm in both cell types, a localization pattern similar to that of c-Abl (Fig. 5). Although Pag lacks a canonical nuclear localization signal, it could be translocated into the nucleus by association with other proteins such as Abl or enter pas- sively because of its small size (Dingwall and Laskey 1991).

Pag inhibits phosphorylation by $\mathrm{Abl}$ in an in vitro kinase assay

Although c-Abl is not normally tyrosine phosphorylated in vivo, Abl tyrosine kinase activity, measured as autophosphorylation or phosphorylation of a physiological substrate such as c-Crk, can be readily detected after immunoprecipitation of c-Abl (Pendergast et al. 1991a). This suggests that cellular inhibitors of Abl may be partially or completely purified away during the immunoprecipitation process. We reasoned that overexpression of Pag might restore inhibition to $\mathrm{Abl}$ in an immune complex kinase assay. We immunoprecipitated c-Abl, SH3-deleted Abl, Bcr/Abl, and p160 v-Abl from 293T cells cotransfected with Pag, and tested their in vitro kinase activity with gl utathione S-transferase (GST)-C rk as a substrate. Under conditions where significant coimmunoprecipitation of Pag and Abl was detected, Pag inhibited c-Abl autophosphorylation and phosphorylation 

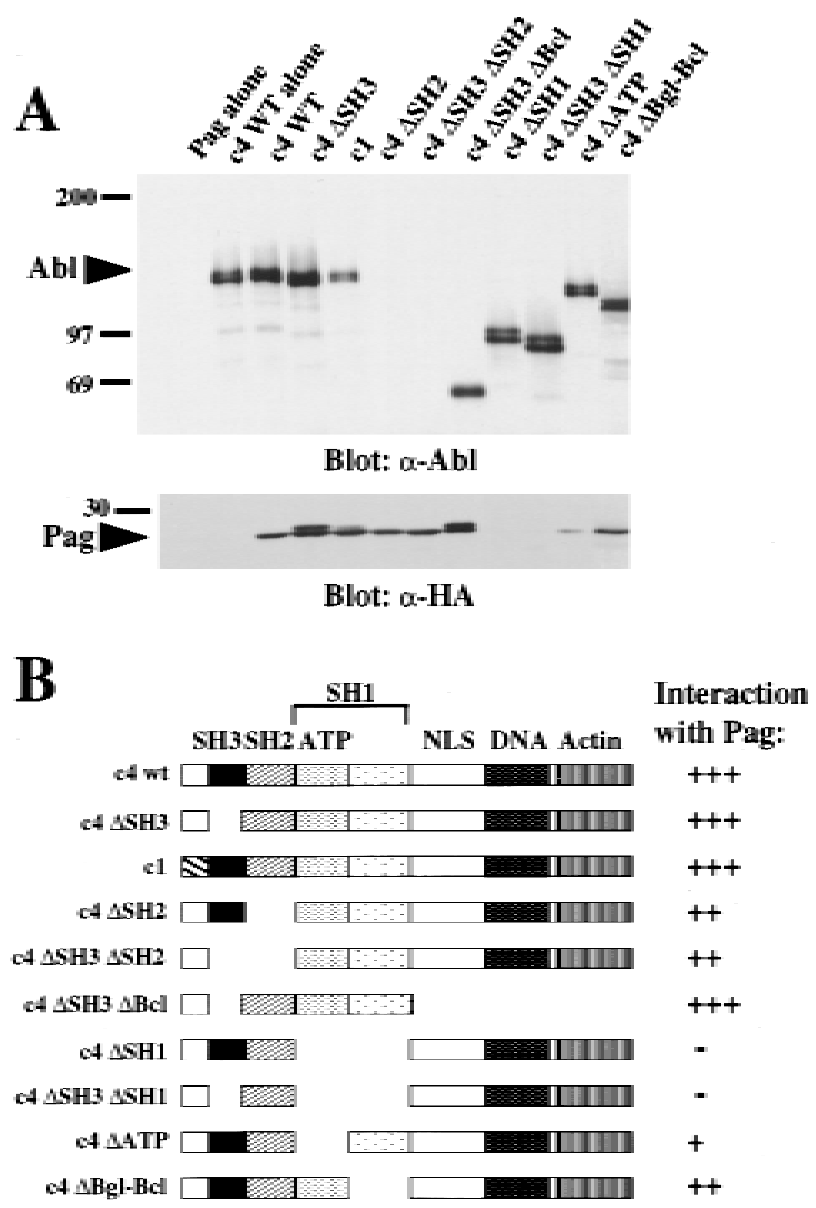

Figure 4. Pag interacts with Abl in vivo. (A) Epitope-tagged Pag and the indicated A bl proteins were coexpressed in 293T cells, cell extracts immunoprecipitated with anti-Abl antisera $\alpha$ GEX4 (directed against the carboxyl terminus of A bl) (Jackson et al. 1993) or $\alpha$-type Ib Abl antisera (directed against the Abl amino terminus, for the $\mathrm{C} 4 \Delta \mathrm{SH} 3 \Delta \mathrm{Bcl}$ protein), and immunoblotted with anti-HA mAb 12CA5 for the detection of Pag or anti-A bl Ab 8E9 (directed against the $\mathrm{SH} 2$ domain of $\mathrm{Abl}$ ). The $\triangle \mathrm{SH} 2$ proteins were detected with a different anti-Abl $\mathrm{Ab}$ and found to be expressed at equivalent levels (data not shown). Coimmunoprecipitation of $\mathrm{Abl}$ with Pag was also observed when the anti-HA mA b was used for immunoprecipitation (data not shown). (B) Schematic representation of Abl deletion constructs and their interaction with Pag as measured by coimmunoprecipitation. The location of the $\mathrm{SH} 3, \mathrm{SH} 2$, and $\mathrm{SH} 1$ domains, the ATP-binding lobe of the kinase domain, the pentalysine nuclear localization signal, and the DNA-binding and actin-binding domains are indicated.

of GST-Crk in vitro by $60 \%-70 \%$, whereas it had no significant effect on the in vitro kinase activity of SH3deleted $\mathrm{Abl}$ and $\mathrm{V}-\mathrm{Abl}$, which lacks the $\mathrm{Abl} \mathrm{SH} 3$ domain (Fig. 6A). Interestingly, Pag did inhibit the auto- and transkinase activity of Bcr/Abl by $30 \%$ (Fig. 6A).

By analogy to c-Src, tyrosine phosphorylation of c-A bl may stimulate Abl tyrosine kinase activity (Cooper and MacAuley 1988). Because coexpression of Pag and c-Abl in 293T cells suppresses tyrosine phosphorylation of Abl, the lower kinase activity of immunoprecipitated Abl might merely reflect decreased Abl tyrosine phosphorylation. To address this, we tested whether overexpression of Pag could inhibit the in vitro kinase activity of endogenous c-Abl after immunoprecipitation from $\mathrm{NIH}-3 \mathrm{~T} 3$ cells. We overexpressed Pag transiently in $\mathrm{NIH}-3 \mathrm{~T} 3$ cells together with human ICAM-1 as a cell surface marker, sel ected positively transfected cel Is with magnetic beads coated with antibody against huICAM-1, immunoprecipitated endogenous c-A bl, and performed an in vitro kinase assay with GST-Crk as a substrate. Overexpression of Pag had a significant (60\%) inhibitory effect on the phosphorylation of GST-Crk by c-Abl, although it had less effect on the autophosphorylation of endogenous C-Abl (Fig. 6B).

These results showed that Pag had an inhibitory effect on Abl kinase activity in vitro when both Pag and Abl were purified from cells, but did not rule out the possibility that additional factor(s) coimmunoprecipitating with $\mathrm{Abl}$ and Pag were necessary for inhibition. To determine whether Pag protein could directly inhibit cAbl, we purified hexahistidine-tagged c-Abl from transfected 293T cells by affinity chromatography on N ickelagarose (B. Brasher and R.A. Van Etten, unpubl.), and tested whether the kinase activity of $(\mathrm{His})_{6}-\mathrm{C}-\mathrm{Abl}$ was inhibited by the addition of a GST-Pag fusion protein. When Pag was added at 10- to 15-fold molar excess over
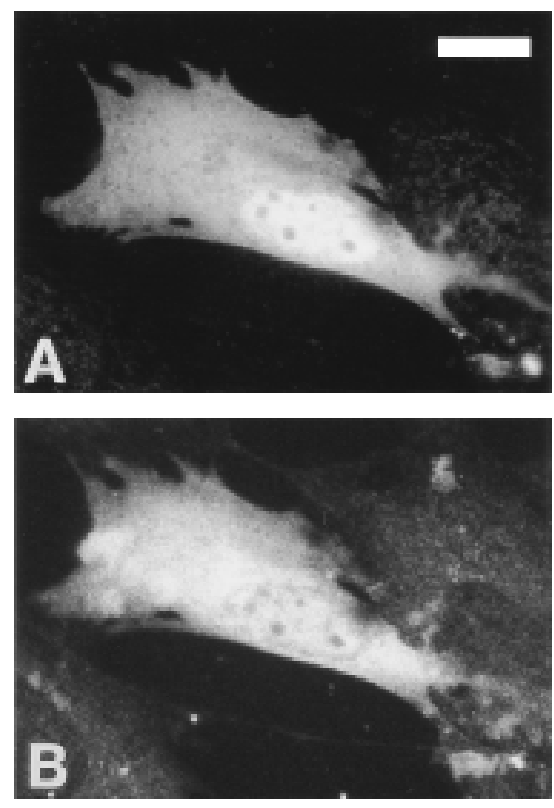

Figure 5. Pag is local ized to nucleus and cytoplasm. NIH-3T3 cells were transfected with epitope-tagged Pag and type IV c-A bl and the expressed proteins were localized with indirect immunofluorescence with rabbit anti-A bl antibodies (A) and anti-HA mAb 12CA5 (B). Background staining levels are indicated by several nontransfected cells in the field. Cells transfected with Pag or Abl al one and stained with the opposite secondary antibody gave similar background staining (data not shown). Bar, 10 $\mu \mathrm{m}$. 

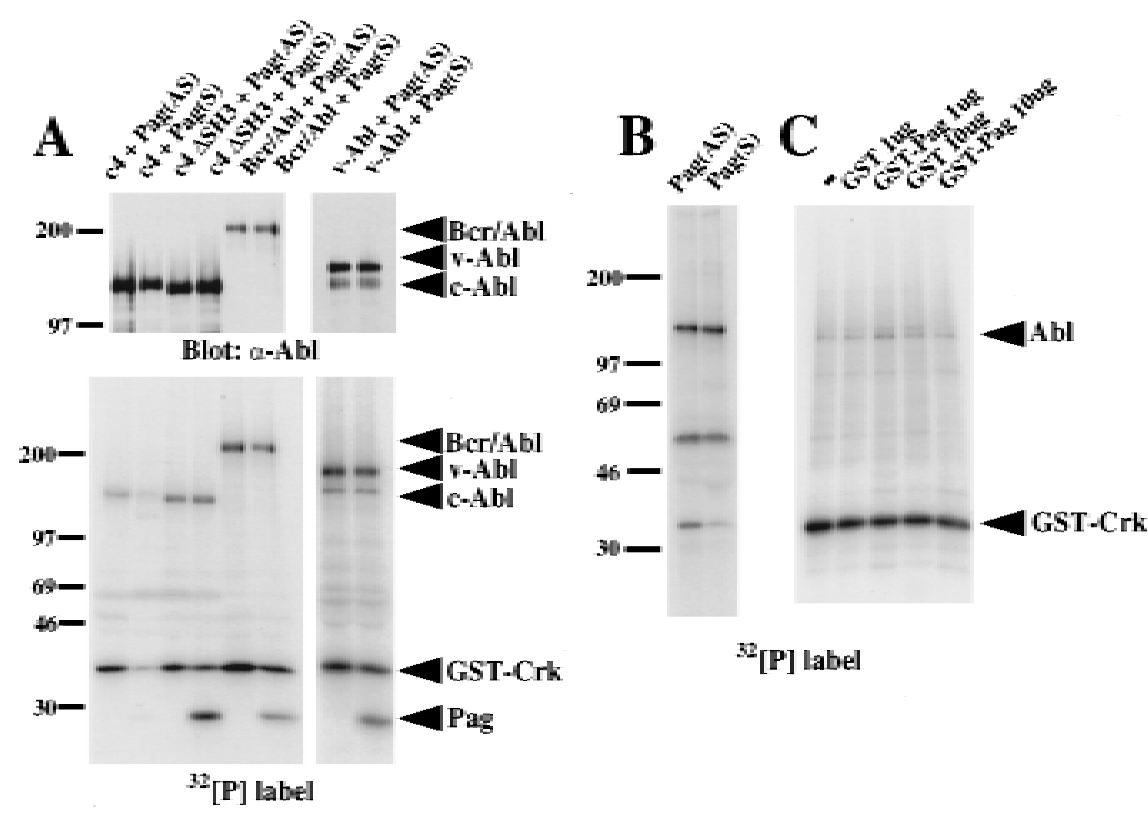

Figure 6. Paginhibits Abl kinase activity in vitro. (A) 293T cells cotransfected with Pag and wild-type c-A bl, SH3-del eted Abl (c4 $\Delta \mathrm{SH} 3$ ), Bcr/Abl, or p160 v-Abl were immunoprecipitated with anti-Abl antibody and immune complex kinase assays performed with GST-Crk as a substrate. (Top) Western blot with anti-Abl antibody showing equivalent amounts of $\mathrm{Abl}$ proteins were immunoprecipitated. (Bottom) Autoradiograph showing ${ }^{32} \mathrm{P}$ incorporation. (B) NIH-3T 3 cells were transfected with Pag in either sense (S) or antisense (AS) orientation and hulCAM-1 as a cellsurface marker, selected with magnetic beads, immunoprecipitated with anti-Abl $A b$, and immune complex kinase assays performed with GST-Crk as a substrate. (C) $(\mathrm{His})_{6}$-purified Abl protein was tested for its in vitro kinase activity with GSTCrk as a substrate and increasing amounts of parental GST or GST-Pagfusion protein added.
c-Abl, there was no inhibition of Abl kinase activity as measured by phosphorylation of GST-Crk (Fig. 6C). Only when Pag was added at higher (40- to 75-fold) molar excess over Abl was a modest decrease in GST-Crk phosphorylation observed (data not shown). These results suggest that Pag alone is unable to inhibit Abl kinase activity, but requires the presence of one or more additional cellular factors for efficient inhibition of c-A bl.

Pag rescues the cytostatic effect of c-Abl in NIH-3T3 cells

c-A bl has been reported to contribute to $\mathrm{G}_{1}$ arrest (Yuan et al. 1996) and apoptosis (Y uan et al. 1997) in response to ionizing radiation in fibroblasts. Overexpression of Abl in NIH-3T 3 cells leads to growth arrest in $\mathrm{G}_{1}$ of the cell cycle (Jackson and Baltimore 1989; Sawyers et al. 1994), an effect that requires nuclear local ization of $A b l$, Abl kinase activity, and the p53 and Rb tumor suppressor gene products (Wen et al. 1996). The mechanism of the Abl cytostatic effect is not known, but likely involves activation of c-A bl kinase in the nucleus of transfected cells. If Pag is a bona fide A bl inhibitor, it should be able to abrogate this $G_{1} / S$ cell cycle block. Importantly, cotransfection of Pag in the sense, but not antisense, orientation rescued the cytostatic effect induced in NIH-3T 3 cells by c-Abl, but Pag had no effect on the cytostatic effect induced by SH3-mutated Abl, P131L (Fig. 7), nor did expressi on of Pag al one have any effect on the $G_{1} / S$ transition. Coexpression of Pag also dramatically increased the transfection efficiency of c-A bl in this assay (Fig. 7), suggesting that Pag also rescues the cytotoxic effect of c-A bl. These results suggest that Pag may normally function to inhibit negative growth and apop-

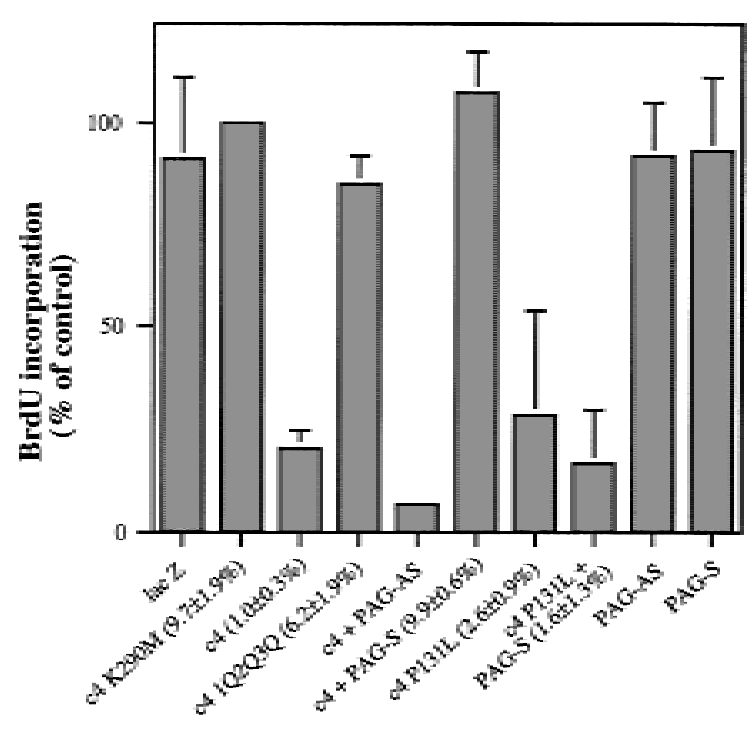

Abl construct

Figure 7. Pag rescues the cytostatic and cytotoxic effects induced by C-A bl. NIH-3T 3 cells were transfected with the indicated Abl constructs with or without PAG in the sense (S) or antisense (AS) orientation, and entry into the $S$ phase of the cell cycle was measured as the percentage of transfected cells positive for BrdU incorporation relative to kinase-inactive Abl. (LacZ) Transfection of the $\beta$-galactosidase reporter construct al one; (c4) c-A bl type IV; (K290M) kinase-inactivating point mutant; (1Q2Q3Q) site-specific mutations in the first, second, and third Abl nuclear localization signals; (P131L) activated SH3 point mutant of c-Abl; (PAG-S and PAG-AS) cotransfection of a PAG expression vector in the sense or antisense orientation, respectively. The transfection efficiency (absolute percentage of $\beta$-galactosidase positive cells) is shown in parentheses after the construct name. 
totic responses associated with activation of nuclear cAbl.

\section{Discussion}

A large body of experimental evidence suggests that Srclike tyrosine kinases are negatively regulated by intramolecular interactions. Src family kinases such as c-Src and $\mathrm{Hck}$ are inhibited by interaction of a phosphorylated tyrosine (residue 527 in c-Src) in the carboxy-terminal tail with the $\mathrm{SH} 2$ domain, with the $\mathrm{SH} 3$ domain al so participating (Sicheri et al. 1997; Xu et al. 1997). Kinases of the Tec family, including Btk and Itk, are likely to be negatively regulated by intramolecular association of the SH3 domain with an adjacent proline-rich domain (Andreotti et al. 1997). It is unlikely that c-Abl is similarly regulated by intramol ecular interactions, however. First, A bl has no Tyr 527 homolog in its carboxyl terminus and is not tyrosine-phosphorylated in the inactive state (Jackson and Baltimore 1989). Second, although mutation of the conserved FLVRES motif in the SH 2 domain activates C-Src (Hirai and Varmus 1990a,b), the same mutation in the A bl SH2 domain abolishes fibroblast transformation by activated Abl ( $M$ ayer et al. 1992). Third, $\mathrm{SH} 3$-deleted or mutated $\mathrm{Abl}$ does not have increased tyrosine kinase activity in vitro (M ayer and Baltimore 1994; Van Etten et al. 1995), but Src proteins with deletions of the $\mathrm{SH} 3$ or $\mathrm{SH} 2$ domain have elevated in vitro kinase activity (Seidel-Dugan et al. 1992). Fourth, although we have detected binding of the $\mathrm{Abl} \mathrm{SH} 3$ domain to a region in the carboxyl terminus of Abl (R.A. Van Etten, unpubl.), deletion of the carboxyl terminus does not activateAbl in vitro or in vivo. Taken together, these observations indicate that $\mathrm{Abl}$ and Src-like kinases are regulated by different mechanisms.

The existence of a cellular A bl inhibitor has been suggested by several lines of evidence, as mentioned previously. By use of a yeast two-hybrid system with the Abl $\mathrm{SH} 3$ domain fusion protein as a bait, we isolated several $\mathrm{Abl} \mathrm{SH} 3$ domain interacting cl ones. One of these clones, the PAG gene, encodes a polypeptide that has many properties expected of a physiological inhibitor of c-A bl. First, Pag interacts specifical ly with $\mathrm{Abl} \mathrm{SH} 3$ domain in the yeast system, and not with other $\mathrm{SH} 3$ domains from c-Src, Grb-2, or the PI3K p85 subunit. Second, when Pag and Abl are coexpressed in 293T cells, Pag inhibits the tyrosine phosphorylation induced by wild-type $A b l$ but not that induced by $\mathrm{Abl} \mathrm{SH} 3$ domain del etion $(\triangle \mathrm{SH} 3)$ and point (P131L) mutants. Further, the inhibition of tyrosine phosphorylation is both Abl-specific, as Pag has no effect on the closely related c-Src tyrosine kinase, and Pag-specific, as inhibition of c-Abl is not observed with other Abl SH3 domain-binding proteins such as Mena, Abi-1, and Abi-2. Third, Pag and Abl associate in vivo, as shown by coimmunoprecipitation. Fourth, Pag inhibits phosphorylation by $\mathrm{Abl}$ in an in vitro kinase assay by use of GST-Crk as a substrate. Finally, Pag rescues the cytostatic effect induced by c-A bl in NIH-3T 3 cells, lending further support to the physiological significance of Pag.
Pag is the first $\mathrm{Abl} \mathrm{SH} 3$ domain-interacting protein that can inhibit Abl kinase activity both in vivo and in vitro. Three other genes have been cloned by use of the two-hybrid screen in the search for Abl inhibitors. Abi-1 and Abi-2 are members of a family of SH3-containing proteins that have homology to homeobox transcription factors. Abi- 1 binds to the carboxyl terminus of $A b l$ and can suppress v-A bl transformation (Shi et al. 1995). A bi2 , identified with the $\mathrm{Abl} \mathrm{SH} 3$ domain as a bait, also binds to the carboxyl terminus of $A \mathrm{bl}$. Coexpression of a carboxy-terminal fragment of $\mathrm{Abi}-2$ with c-Abl in fibrobl asts appears to activate transformation by Abl (Dai and Pendergast 1995). Abi-1 and Abi-2, however, have not been shown directly to inhibit c-A bl kinase activity, but rather have some properties that suggest they may be effectors of Abl function. The AAP1 protein, isolated with the Abl SH3-SH2 domain as a bait, decreases the phosphorylation of GST-Crk by Abl in vitro (Zhu and Shore 1996); however, no in vivo role for AAP1 has been shown.

Pag appears to interact with $\mathrm{Abl}$ in vivo through multiple domains. Pag was initially identified in our twohybrid screen as an SH3-interacting protein. Although some prolines are present in the Pag sequence, they do not form the consensus PXXP, a motif that has been shown to bind to SH3 domains (Cicchetti et al. 1992; Ren et al. 1993). The failure of Pag to interact with the P131L SH3 domain in yeast, however, strongly suggests Pag binds to $\mathrm{SH} 3$ via the same ligand-binding surface occupied by PXXP-containing ligands. The PXXP-binding motif was identified with combinatorial peptide (Feng et al. 1994; Yu et al. 1994) or phage display (Rickles et al. 1994, 1995) libraries to select SH3-binding sites, which may select for peptide ligands with prolines at $i$ and $i+3$ positions because of the requirement for polyproline II (PPII) helix formation for SH 3 binding. Because polypeptides lacking proline can al so assume a PPII conformation (Adzhubei and Sternberg 1993), it is possible that other classes of $\mathrm{SH} 3$ ligand exist. In support of this, in the three-dimensional crystal structure of c-Src, the $\mathrm{SH} 3$ domain and kinase domain are closely apposed by interaction of $\mathrm{SH} 3$ with a 14-residue polypeptide linker that contains only one proline, but adopts a PPII helical conformation in complex with the SH 3 domain (Xu et al. 1997). The Pag protein may assume a similar conformation in making contact with the $\mathrm{Abl} \mathrm{SH} 3$ domain. The location of the SH3-binding site in Pag is currently under investigation, but can be inferred to be in the carboxyl terminus, because a B42-Pag fusion protein containing only the carboxy-terminal 79 amino acids of Pag binds strongly to the Abl SH3 domain in yeast (Fig. 1).

Interestingly, Pag appears to interact with both the $\mathrm{SH} 3$ and the kinase domains of $\mathrm{Abl}$ in vivo. Indeed, the interaction of Pag with the kinase domain appears to be quantitatively more important than the $\mathrm{SH} 3$ interaction for coimmunoprecipitation of Pag and Abl. This might reflect the relatively low (micromolar) binding affinity observed for SH3-ligand interactions (Feng et al. 1994; Van Etten et al. 1995). A nalysis of A bl deletion mutants suggests that Pag interacts with the amino-terminal por- 
tion of the kinase domain, which comprises the ATPbinding lobe. In this respect, the interaction of Pag with Abl is reminiscent of cyclin-dependent kinase inhibitors. Mutagenesis of the p21 WAF1/CIP1 $c y c l i n-d e p e n d e n t ~ k i-$ nase inhi bitor reveals independent binding sites for cycIin and cdk2, both of which are required for inhibitory activity (Fotedar et al. 1996); this type of interaction is confirmed in the structure of the the p27 ${ }^{\mathrm{Kip} 1}$ cyclin-dependent-kinase inhibitor, which binds to the cyclin Acdk2 complex by making contact with both the cyclin A subunit and the ATP-binding lobe of cdk2 (Russo et al. 1996). It is possible that Pag does not contact the kinase domain directly, however, because Pag failed to interact with the $\mathrm{SH} 1$ domain in yeast. Also, Pag was unable to efficiently inhibit c-Abl kinase activity when the two purified proteins were mixed in vitro. Failure of GSTPag to inhibit purified c-Abl might again reflect a low binding affinity of Pag for $\mathrm{Abl}$ and the concentration of Pag (2-5 $\mu \mathrm{M})$ that we used, but the strength of induction of the lacZ reporter gene by B42-Pag in yeast (Fig. 2) was suggestive of a considerably stronger Pag-SH3 association, on the order of 50-100 nм (Gyuris et al. 1993). Another possibility is that addition of the GST moiety to the amino terminus of Pag interferes with its function as an inhibitor, which seems unlikely because Pag can tolerate addition of an epitope tag (consisting of 22 amino acids) at its amino terminus and retain inhibitory function in vivo. The most plausible explanation is that Pag may require another cellular factor to inhibit $A b l$ efficiently, and it is possible that this factor makes direct contact with the catalytic cleft of the Abl kinase domain. The use of Pag as the bait in a two-hybrid screen might help to identify this cofactor.

Pag only weakly inhibited the in vitro kinase activity of $\mathrm{Bcr} / \mathrm{Abl}$ fusion protein of human chronic myelogenous leukemia (Fig. 6A), and coexpression of Pag did not decrease the level of tyrosine phosphorylation induced by $\mathrm{Bcr} / \mathrm{Abl}$ in vivo (data not shown). This is interesting because the Bcr/Abl protein retains the A bl SH 3 domain. The Bcr moiety of the fusion protein contains a coiledcoil oligomerization domain (M cWhirter et al. 1993) and a region which mediates binding to the $\mathrm{Abl} \mathrm{SH} 2$ domain (Pendergast et al. 1991b), both of which are required for $\mathrm{Bcr} / \mathrm{Abl}$ transforming activity. In addition, Bcr/Abl exhibits elevated in vitro kinase activity relative to c-Abl (Lugo et al. 1990), whereas deletion of the Abl SH2 domain reduces the in vitro kinase activity of $\mathrm{Bcr} / \mathrm{Abl}$ to that of c-A bl (Ilaria and Van Etten 1995). These observations suggest that the kinase activity of $\mathrm{Bcr} / \mathrm{Abl}$ is stimulated by inter- or intramolecular interactions mediated by $\mathrm{Bcr}$ and $\mathrm{Abl} \mathrm{SH} 2$, and it is plausible that the $\mathrm{SH} 3$ domain of Bcr/Abl may be inaccessible to ligands such as Pag as a consequence.

The PAG gene was cloned by differential screening of cDNA libraries from an untransformed and ras-transformed human mammary epithelial cell line (Prosperi et al. 1993). It is fairly ubiquitously expressed, as is c-A bl, and is induced to higher levels with serum stimulation. The murine homolog of Pag, MSP23, was cloned as a CDNA induced in mouse peritoneal macrophages by oxi- dative stress (Ishii et al. 1993). Like Pag, MSP23 is widely expressed among various tissues under normal conditions. Pag/M SP23 has homology to a growing family of proteins from prokaryotes and eukaryotes, many of which function as peroxide reductases (Chae et al. 1994a), and purified MSP23 has been shown to have thiol-specific antioxidant activity in vitro (Ishii et al. 1995). Additional functional roles are suggested for several members of this family. The MER5 gene was identified as a cDNA induced during early differentiation of murine erythroleukemia (MEL) cells (Yamamoto et al. 1989), and antisense-mediated inhibition of MER5 expression partially blocks MEL cell differentiation ( $\mathrm{Ne}$ moto et al. 1990). A close relative of Pag, N KEF-A, was originally identified as a factor capable of enhancing natural killer cell cytotoxicity (Shau et al. 1994).

Our results suggest an additional function for Pag/ MSP23: inhibition of c-Abl kinase activity. It is unlikely that antioxidant activity of Pag is responsible for this inhibition, because we have observed significant suppression of $\mathrm{Abl}$-induced tyrosine phosphorylation with amino-terminal truncation mutants of Pag that lack the conserved Cys52 residue required for antioxidant activity (Chae et al. 1994b), (data not shown). Abl SH3-binding and kinase inhibition is, therefore, likely to represent a distinct function of Pag. Oxidative stress induces a plei otropic physiologic response in mammalian cells, including induction of antioxidant proteins, protein-tyrosine phosphatases, and transcription factors such as cJun and NF-kB (Sies 1993). It is provocative that c-Abl kinase activity is stimulated by ionizing radiation and radiomimetic chemicals such as mitomycin $C$ and cisplatin, both of which induce DNA damage via generation of free radicals. It is possible that the direct activation of c-Abl by these stimuli is mediated by free radicals, causing dissociation of Pagand increased enzymatic activity of both Abl and Pag, whereas the subsequent increase in Pag level s restores inhibition to Abl as part of a negative feedback response.

Pagmight al so play a role in regulating the cell cyclein the absence of oxidative stress. Dominant negative and antisense approaches suggest c-A bl may inhibit the $G_{0}$ to $\mathrm{G}_{1}$ transition in fibroblasts (Sawyers et al. 1994; Daniel et al. 1995). It is possible that up-regulation of Pag with serum stimulation serves to relieve an Abl-dependent block to cell cycle entry. In addition, as an inhibitor of a proto-oncogene, PAG is also a candi date tumor suppressor gene. It is of interest that structural al terations of the chromosome 1p34.1, where PAG is located (Prosperi et al. 1994), are not infrequent in several types of human cancer, with translocations involving 1p34 in leukemia, particularly acute lymphoblastic leukemia (ALL), and deletions of distal 1p frequent in ALL, breast cancer, and neuroblastoma (Mitel man 1994).

\section{Materials and methods}

Cells and cell culture

NIH-3T3 and 293T cells were the kind gift of L. Klickstein (Brigham and Women's Hospital, Boston, MA). NIH-3T 3 cells 
were propagated in Dulbecco's modified Eagle medium (DMEM) with 4.5 grams/liter of glucose, $10 \%$ calf serum, and penicillin/streptomycin. 293T cells were grown in DMEM, $10 \%$ heat-inactivated fetal calf serum, glutamine, nonessential amino acids, and penicillin/streptomycin.

\section{DNA constructs}

A CDN A fragment encoding the c-A bl SH 3 domain (amino acids 72-138) was excised from pPLc4 Abl (Van Etten et al. 1989) by $\mathrm{Xmnl}-\mathrm{Hincll}$ restriction enzyme digestion, then fitted with BamHI linkers and subcloned in frame into the plasmid Lex202+PL (kind gift of R. Brent, M assachusetts General Hospital, Boston). The resultant plasmid LexA-Abl SH3 directed the synthesis of a fusion protein containing the LexA DNAbinding domain and the $\mathrm{SH} 3$ domain of $\mathrm{Abl}$ when expressed in yeast strain EGY48. A similar strategy was used to generate yeast expression plasmids for the LexA-c-Src SH3 (amino acids 85-145), LexA-PI3K p85 SH3 (amino acids 1-85), LexA-Grb2 $\mathrm{N}$-SH 3 (amino acids 4-60), LexA-Abl SH 1 (amino acids 239540), and LexA-Abl carboxyl terminus.

The PAG cDNA was a generous gift of G. Goubin (Institut Curie, Paris, France). To express Pag in mammalian cells, the entire PAG CDNA was subcloned in-frame into pCGN (obtained from W. Herr, Cold Spring Harbor Laboratory, NY) at the BamHI site downstream of the sequence encoding the hemagglutinin (HA) tag.

The mammalian expression vector pcDNA-c4 Abl and its various internal deletion mutations have been described previously (Wen et al. 1996). To generate the kinase domain del etion mutants, the plasmid pGDN-Abl (kind gift of B. Mayer; Mayer and Baltimore 1994), in which a BamHI site had been created at the beginning of the kinase domain, was used. Constructs with deletion of the entire kinase domain or just the ATP-binding Iobe were generated by BamHI-Bcll or BamHI-Bglll digestion respectively, fusing the ends in-frame, and subcloning the deleted cDNAs back into pcDNA vector. The GSC-Abl-SrcTK chimera plasmid (also a gift of B. Mayer; Mayer and Baltimore 1994) was similarly subcloned into the pcDN A vector.

For production of bacterial fusion protein, the PAG CDNA was subcloned in-frame into pGEX-4T-2 (Pharmacia) at the BamHI site. pGEX-2T-Crk (amino acids 120-225) and pGEX4T-2-Pag were introduced into the Escherichia coli host strain NB42 $F^{\prime}$, and GST fusion proteins purified by affinity chromatography on glutathione-agarose (M olecular Probes) as described (Van Etten et al. 1989).

The cDNA-encoding murine Mena was a generous gift of $F$. Gertler (Fred Hutchinson Cancer Research, Seattle, WA). The entire coding sequence of $M$ ena was subcloned in-frame into pCGN mammalian expression vector. A CDNA encoding the full-length Abi-1 protein was the kind gift of S. Goff (Columbia University School of Medicine, N ew York, NY) and was cloned into pcDNAI. The pCGN-Abi-2 plasmid was a kind gift of A.M. Pendergast (Duke University Medical Center, Durham, NC). pFLAG-Rb SE was a gift of J. Wang (University of California, San Diego). The pBSK-c-Src and pBSK-c-Src Y527F were gifts of D. M organ (University of Cal ifornia, San Francisco); the entire coding sequence of these two cDN As were subcloned in frame into pcD N AI. The pCDM 8-hulCAM-1 was a gift of T. Springer (Harvard Medical School, Boston, MA).

\section{Yeast two-hybrid screen}

A genetic screen using the yeast interaction trap was performed as described (Gyuris et al. 1993; Zervos et al. 1993). The bait plasmid LexA-Abl SH3 was transformed into yeast strain
EGY 48 with a reporter plasmid (JK103) that contained the LexAop-LEU 2 reporter gene. This strain was transformed with the HeLa interaction library, generated by fusion of CDNAs with the activation domain carried on the B42 acid bl ob (Zervos et al. 1993). Yeast transformation was performed by the lithium acetate method (Gietz et al. 1992). Ten million primary library transformants were amplified and screened. Seven hundred and fifty interacting clones were selected as meeting the following criteria: (1) They grew on $\mathrm{Ura}^{-} \mathrm{His}^{-} \mathrm{Trp}^{-} \mathrm{Leu}^{-}$-galactose plates but not on Ura- $\mathrm{His}^{-} \mathrm{Trp}^{-} \mathrm{Leu}^{-}$-glucose plates; and (2) they turned blue on U $\mathrm{ra}^{-} \mathrm{His}^{-} \mathrm{Trp}^{-} \mathrm{X}$-gal-gal actose plates but not on $\mathrm{U} \mathrm{ra}^{-} \mathrm{His}^{-} \mathrm{Trp}^{-} \mathrm{X}$-gal-glucose plates. Plasmids from these interacting clones were isolated by transformation of $\mathrm{E}$. coli strain KC8. To test whether the library CDN As encoded proteins that interacted specifically with the Abl SH3 domain, the library clones were transformed back into yeast al ong with either LexA-Abl SH3, LexA-Abl SH3 (P131L), LexA-Bicoid, LexA-cdc2, or LexA-Integrin. Those clones that interacted with $\mathrm{SH} 3$ (P131L) or the nonspecific baits were not considered further. The remaining specific interacting clones ( 200 clones) were DNA sequenced with dideoxy sequencing according to the manufacturer's directions (U.S. Biochemical).

\section{Transfections and Abl cytostatic assay}

Calcium phosphate transfection of 293T cells was performed as described (Van Etten et al. 1995). LipofectAMINE was used to transfect N IH-3T 3 cells according to manufacturer's directions (GIBCO/Life Technologies). For the analysis of cell cycle arrest by $\mathrm{Abl}$, the cells were labeled with 5-bromo-2-deoxyuridine (BrdU), then analyzed with immunofluorescence and histochemical staining as described previously (Wen et al. 1996). In some experiments, NIH-3T 3 cells cotransfected with the huICAM -1 expression plasmid were positively sel ected by staining cells with the anti-hulCAM-1 mAb R6-5 and anti-mouse microbeads, followed by selection on a MicroMACS column (Miltenyi Biotec).

\section{Protein analysis}

Proteins were analyzed by direct Western blotting or blotting after immunoprecipitation. 293T cell extracts containing equival ent amounts of $\mathrm{Abl}$ proteins were immunoprecipitated with anti-GEX4 antibody (directed against carboxy-terminal Abl sequences) as described (Van Etten et al. 1995), or with anti-exon Ib c-A bl antibody (gift of O. Witte, University of California, Los Angeles), then blotted with either anti-HA 12CA5 $\mathrm{mAb}$ (BabCo), anti-phosphotyrosine mAb 4G10 (Upstate Biotechnology, Inc.), or anti-A bl SH 2 domain antibody 8E9 (Pharmingen), and devel oped with enhanced chemiluminescence (Amersham). For ${ }^{35} \mathrm{~S}$-labeling of proteins, cells were labeled overnight with ${ }^{35} \mathrm{~S}$-EXPRESS Protein labeling mix (125 $\mu \mathrm{Ci} /$ plate, $\mathrm{N}$ ew England Nuclear), and extracts prepared and immunoprecipitated with anti-GEX4 antisera under conditions of quantitative immunoprecipitation of Abl. Immunoprecipitated proteins were resolved by SDS-PAGE and detected by autoradiography utilizing Amplify fluorescence enhancement (Amersham).

\section{In vitro kinase assay}

The immune complex kinase was performed as described (Konopka and Witte 1985; Jackson and Bal timore 1989). The kinase reaction was carried out in $50-100 \mu \mathrm{l}$ of kinase buffer containing $20 \mathrm{~mm}$ PIPES at pH 7.2, $20 \mathrm{~mm} \mathrm{MnCl}, 0.5 \mu \mathrm{g} \mathrm{GST}-C r k$, and 0.2 $\mu \mathrm{l}$ of $\left[\gamma^{-32} \mathrm{P}\right]$ ATP $(10 \mathrm{mCi} / \mathrm{ml})$ at room temperature for $20 \mathrm{~min}$. 
The proteins were eluted in Laemmli sample buffer and analyzed by SDS-PAGE and autoradiography. For the in vitro kinase assay with purified $\mathrm{Abl}$, ( $\mathrm{His})_{6}$-tagged $\mathrm{Abl}$ was purified from $293 T$ cells with nickel-agarose (Qiagen), eluted with $80 \mathrm{~mm}$ imidazole in high salt buffer $(500 \mathrm{~mm} \mathrm{~N} \mathrm{aCl}, 20 \mathrm{~mm}$ HEPES at $\mathrm{pH}$ 7.5), and concentrated with centricon-10 microfiltration unit (A micon) (B. Brasher, unpubl.). GST or the GST-Pag fusion protein, purified from E. coli by affinity chromatography on glutathione-agarose, was added in 1.5- to 15-fold molar excess (corresponding to a Pag concentration of 0.2-2.0 $\mu \mathrm{M}$ ) or 7.5- to 75 -fold molar excess relative to $\mathrm{Abl}$ protein and the kinase re action performed under similar conditions. Results were quantitated by densitometry and by PhosphorImager analysis.

\section{Immunofluorescence}

NIH-3T 3 and 293T cells transfected with pCGN-PAG and pcDNA-c4 Abl were fixed with methanol and acetone and stained with anti-HA mAb 12CA5 and affinity-purified rabbit antiGEX4 Abl antibodies, followed by rhodamine-conjugated donkey anti-rabbit IgG and fluorescein-conjugated donkey antimouse IgG (Jackson Immunoresearch), as described (Wen et al. 1996). Expressing cells were photographed on a Zeiss Axiophot microscope with Tmax ASA 400 black-and-white film (Kodak).

\section{Acknowledgments}

We thank Dr. Roger Brent for kindly providing the yeast twohybrid cloning system; Dr. Gerard Goubin for the generous gift of the CDN A of the PAG gene; Dr. Frank Gertler for the CDNA of Mena, anti-Mena antibody, and sharing unpublished data; Bradley Brasher for the pcDNA-Abl (His) 6 construct; Dr. Stephen Goff for the CDNA clone of Abi-1; Dr. Ann Marie Pendergast for the cDN A clone of A bi-2; Dr. Jean Wang for the pFLAG$\mathrm{Rb}$ SE plasmid; Dr. David Morgan for the CDNA of C-Src and c-Src Y527F; Dr. Bruce Mayer for the Abl-SrcTK chimera and Abl $\triangle \mathrm{SH} 2$ mutant; Dr. Timothy Springer for the CDNA of huICAM-1 and the anti-huICAM-1 antibody; Dr. Owen Witte for the anti-A bl type Ib antibody; and Dr. Peter Jackson for reading the manuscript and many helpful discussions. This work was supported in part by a grant from the Lucille P. Markey Charitable Trust. R.A.V. is a Lucille P. M arkey Scholar in Biomedical Science and The Carl and Margaret Walter Scholar in Blood Research at Harvard Medical School.

The publication costs of this article were defrayed in part by payment of page charges. This article must therefore be hereby marked "advertisement" in accordance with 18 USC section 1734 solely to indicate this fact.

\section{References}

Adzhubei, A.A. and M.J. Sternberg. 1993. Left-handed poly-proline II helices commonly occur in globular proteins. J. Mol. Biol. 229: 472-493.

Andreotti, A.H., S.C. Bunnell, S. Feng, L.J. Berg, and S.L. Schreiber. 1997. Regulatory intramolecular association in a tyrosine kinase of the Tec family. Nature 385: 93-97.

Chae, H.Z., K. Robison, L.B. Poole, G. Church, G. Storz, and S.G. Rhee. 1994a. Cloning and sequencing of thiol-specific antioxidant from mammalian brain: Alkyl hydroperoxide reductase and thiol-specific antioxidant define a large family of antioxidant enzymes. Proc. Natl. Acad. Sci. 91: 7017-7021.

Chae, H.Z., T.B. Uhm, and S.G. Rhee. 1994b. Dimerization of thiol-specific antioxidant and the essential role of cystein 47. Proc. Natl. Acad. Sci. 91: 7022-7026.
Chien, C.-T., P.L. Bartel, R. Sternglanz, and S. Fields. 1991. The two-hybrid system: A method to identify and clone genes for proteins that interact with a protein of interest. Proc. Natl. Acad. Sci. 88: 9578-9582.

Cicchetti, P., B.J. M ayer, G. Thiel, and D. Baltimore. 1992. Identification of a protein that binds to the $\mathrm{SH} 3$ region of $\mathrm{Abl}$ and is similar to Bcr and GAP-rho. Science 257: 803-806.

Cooper, J.A. and A. MacAuley. 1988. Potential positive and negative autoregulation of p60c-src by intermolecular autophosphorylation. Proc. Natl. Acad. Sci. 85: 4232-4236.

Dai, Z. and A.M. Pendergast. 1995. Abi-2, a novel SH3-containing protein interacts with the c-Abl tyrosine kinase and modulates c-Abl transforming activity. Genes \& Dev. 9: 2569-2582.

Daniel, R., Y. Cai, P.M.C. Wong, and S.-W. Chung. 1995. Deregulation of $\mathrm{c}$-abl mediated cell growth after retroviral transfer and expression of antisense sequences. Oncogene 10: 1607-1614.

Dingwall, C. and R.A. Laskey. 1991. Nuclear targeting sequences-a consensus? Trends Biochem. Sci. 16: 478-481.

Feller, S.M., B. Knudsen, and H. Hanafusa. 1994. c-Abl kinase regulates the protein binding activity of c-Crk. EMBO J. 13: 2341-2351.

Feng, S., J.K. Chen, H. Yu, J.A. Simon, and S.L. Schreiber. 1994. Two binding orientations for peptides to the Src SH3 domain: Development of a general model for SH3-ligand interactions. Science 266: 1241-1247.

Fotedar, R., P. Fitzgeral d, T. Rousselle, D. Cannella, M. Doree, H. Messier, and A. Fotedar. 1996. p21 contains independent binding sites for cyclin and cdk2: Both sites are required to inhibit cdk2 kinase activity. Oncogene 12: 2155-2164.

Franz, W.M., P. Berger, and J.Y.J. Wang. 1989. Deletion of an $\mathrm{N}$-terminal regulatory domain of the $\mathrm{c}$-abl tyrosine kinase activates its oncogenic potential. EMBO J. 8: 137-147.

Gertler, F.B., K. N iebuhr, M. Reinhard, J. Wehland, and P. Soriano. 1996. M ena, a rel ative of VASP and D rosophila Enabled, is implicated in the control of microfilament dynamics. Cell 87: 227-239.

Gietz, D., A. St. Jean, R.A. Woods, and R.H. Schiestl. 1992. Improved method for high efficiency transformation of intact yeast cells. Nucleic Acids Res. 20: 1425-1427.

Goff, S.P., E. Gilboa, O.N. Witte, and D. Baltimore. 1980. Structure of the abelson murine leukemia virus genome and the homologous cellular gene: Studies with cloned viral DNA. Cell 22: 777-785.

Gyuris, J., E. Golemis, H. Chertkov, and R. Brent. 1993. Cdi 1, a human $\mathrm{Gl}$ and $\mathrm{S}$ phase phosphatase that associates with cdk2. Cell 75: 791-803.

Hirai, H. and H.E. Varmus. 1990a. Mutations in src homology regions 2 and 3 of activated chicken c-src that result in preferential transformation of mouse or chicken cells. Proc. Natl. Acad. Sci. 87: 8592-8596.

- - - 1990b. Site-directed mutagenesis of the SH2- and SH3coding domains of c-src produces varied phenotypes, including oncogenic activation of p60c-src. Mol. Cell. Biol. 10: 1307-1318.

Ilaria, Jr., R.L. and R.A. Van Etten. 1995. The SH2 domain of $\mathrm{P} 210^{\mathrm{BCR} / \mathrm{ABL}}$ is not required for transformation of hematopoietic factor-dependent cells. Blood 86: 3897-3904.

Ishii, T., M. Yamada, H. Sato, M. Matsu, S. Taketani, K. Nakayama, Y. Sugita, and S. Bannai. 1993. Cloning and characterization of a 23-kDa stress-induced mouse peritoneal macrophage protein. J. Biol. Chem. 268: 18633-18636.

Ishii, T., T. Kawane, S. Taketani, and S. Bannai. 1995. Inhibition of the thiol-specific antioxidant activity of rat liver MSP23 protein by hemin. Biochem. Biophys. Res. Comm. 216: 970- 
975.

Iwahara, S., H. Satoh, D.X. Song, J. Webb, A.L. Burlingame, Y. N agae, and U. Muller-Eberhard. 1995. Purification, characterization, and cloning of a heme-binding protein $(23 \mathrm{kDa})$ in rat liver cytosol. Biochemistry 34: 13398-13406.

Jackson, P. and D. Baltimore. 1989. $\mathrm{N}$-terminal mutations activate the leukemogenic potential of the myristoylated form of c-abl. EMBO J. 8: 449-456.

Jackson, P.K., M. Paskind, and D. Baltimore. 1993. Mutation of a phenylalanine conserved in SH3-containing tyrosine $\mathrm{ki}$ nases activates the transforming ability of c-Abl. Oncogene 8: 1943-1956.

Kawai, S., S. Takeshita, M. Okazaki, R. Kikuno, A. Kudo, and E. A mann. 1994. Cloning and characterization of OSF-3, a new member of the MER5 family, expressed in mouse osteoblastic cells. J. Biochem. 115: 641-643.

Kharbanda, S., R. Ren, P. Pandey, T.D. Shafman, S.M. Feller, R.R. Weichselbaum, and D.W. Kufe. 1995. Activation of the c-A bl tyrosine kinase in the stress response to DN A-damaging agents. Nature 376: 785-788.

Kipreos, E.T. and J.Y.J. Wang. 1990. Differential phosphorylation of c-Abl in cell cycle determined by cdc2 kinase and phosphatase activity. Science 248: 217-220.

- - . 1992. Cell cycle-regulated binding of c-A bl tyrosine kinase to DNA. Science 256: 382-385.

Konopka, J.B. and O.N. Witte. 1985. Detection of c-abl tyrosine kinase activity in vitro permits direct comparison of normal and al tered abl gene products. Mol. Cell. Biol. 5: 3116-3123.

Liu, Z.-G., R. Baskaran, E.T. Lea-Chou, L.D. Wood, Y. Chen, M. Karin, and J.Y.J. Wang. 1996. Three distinct signalling re sponses by murine fibroblasts to genotoxic stress. Nature 384: 273-276.

Lugo, T.G., A. Pendergast, A.J. Muller, and O.N. Witte. 1990. Tyrosine kinase activity and transformation potency of bcrabl oncogene products. Science 247: 1079-1082.

Mayer, B.J. and D. Baltimore. 1994. Mutagenic analysis of the roles of $\mathrm{SH} 2$ and $\mathrm{SH} 3$ domains in regulation of the $\mathrm{Abl}$ tyrosine kinase. Mol. Cell. Biol. 14: 2883-2894.

Mayer, B.J., P.K. Jackson, R.A. Van Etten, and D. Baltimore. 1992. Point mutations in the abl SH2 domain coordinately impair phosphotyrosine binding in vitro and transforming activity in vivo. Mol. Cell. Biol. 12: 609-618.

McWhirter, J.R. and J.Y.J. Wang. 1993. An actin-binding function contributes to transformation by the Bcr-Abl oncoprotein of the Philadelphia chromosome-positive leukemias. EMBO J. 12: 1533-1546.

McWhirter, J.R., D.L. Galasso, and J.Y.J. Wang. 1993. A coiledcoil oligomerization domain of Bcr is essential for the transforming function of Bcr-Abl oncoproteins. Mol. Cell. Biol. 13: 7587-7595.

Mitelman, F. 1994. Catalog of chromosome aberrations in cancer. Wiley-Liss, N ew York, NY.

Nemoto, Y., T. Yamamoto, S. Takada, Y. M atsui, and M. Obinata. 1990. Antisense RNA of the latent period gene (MER5) inhibits the differentiation of murine erythroleukemia cells. Gene 91: 261-265.

Pendergast, A.M., J.A. Traugh, and O.N. Witte. 1987. N ormal cellular and transformation-associated abl proteins share common sites for protein kinase $\mathrm{C}$ phosphorylation. Mol. Cell. Biol. 7: 4280-4289.

Pendergast, A.M., A.J. Muller, M.H. Havelik, R. Clark, F. M cCormick, and O.N. Witte. 1991a. Evidence for regulation of the human ABL tyrosine kinase by cellular inhibitor. Proc. Natl. Acad. Sci 88: 5927-5931.

Pendergast, A.M., A.J. Muller, M.H. Havlik, Y. Maru, and O.N . Witte. 1991b. BCR sequences esential for transformation by the $B C R-A B L$ oncogene bind to the $A B L S H 2$ regulatory domain in a non-phosphotyrosine-dependent manner. Cell 66: 161-171.

Pendergast, A.M., M.L. Gishizky, M.H. Havlik, and O.N. Witte. 1993. SH 1 domain autophosphorylation of $\mathrm{P} 210 \mathrm{BCR} / \mathrm{ABL}$ is required for transformation but not growth factor independence. Mol. Cell. Biol. 13: 1728-1736.

Prosperi, M.T., D. Ferbus, I. Karczinski, and G. Goubin. 1993. A human CDNA corresponding to a gene overexpressed during cell proliferation encodes a product sharing homology with amoebic and bacterial proteins. J. Biol. Chem. 268: 1105011056.

Prosperi, M.T., F. Apiou, B. Dutrillaux, and G. Goubin. 1994. Organization and chromosomal assignment of two human PAG gene loci: PAGA encoding a functional gene and PAGB a processed pseudogene. Genomics 19: 236-241.

Ren, R., B.J. Mayer, P. Cicchetti, and D. Baltimore. 1993. Identification of a ten-amino acid proline-rich $\mathrm{SH} 3$ binding site. Science 259: 1157-1161.

Ren, R., S.Y. Zheng, and D. Baltimore. 1994. Abl protein-tyrosine kinase sel ects the Crk adapter as a substrate using SH3binding sites. Genes \& Dev. 8: 783-795.

Rickles, R.J., M.C. Botfield, Z. Weng, J.A. Taylor, O.M. Green, J.S. Brugge, and M.J. Zoller. 1994. Identification of Src, Fyn, $\mathrm{PI} 3 \mathrm{~K}$ and $\mathrm{Abl} \mathrm{SH} 3$ domain ligands using phage display. EMBO J. 13: 5598-5604.

Rickles, R.J., M.C. Botfield, X.M. Zhou, P.A. Henry, J.S. Brugge, and M.J. Zoller. 1995. Phage display selection of ligand residues important for Src homology 3 domain binding specificity. Proc. Natl. Acad. Sci. 92: 10909-10913.

Russo, A.A., P.D. Jeffrey, A.K. Patten, J. Massague, and N.P. Pavletich. 1996. Crystal structure of the $\mathrm{p} 27^{\mathrm{Kip} 1} \mathrm{cyclin}$-de pendent-kinase inhibitor bound to the cyclin A-cdk2 complex. Nature 382: 325-331.

Sawyers, C.L., J.L. McLaughlin, A. Goga, M. Havlik, and O. Witte. 1994. The nuclear tyrosine kinase c-Abl negatively regulates cell growth. Cell 77: 121-131.

Schwartzberg, P.L., A.M. Stall, J.D. Hardin, K.S. Bowdish, T. Humaran, S. Boast, M.L. Harbison, E.J. Robertson, and S.P. Goff. 1991. Mice homozygous for the ab/ ${ }^{\mathrm{ml}}$ mutation show poor viability and depletion of selected B and T cell populations. Cell 65: 1165-1176.

Sefton, B.M., T. Hunter, and W.C. Raschke. 1981. Evidence that the Abelson virus protein functions in vivo as a protein $\mathrm{ki}$ nase that phosphorylates tyrosine. Proc. Natl. Acad. Sci. 78: 1552-1556.

Seidel-Dugan, C., B.E. Meyer, S.M. Thomas, and J.S. Brugge. 1992. Effects of SH2 and $\mathrm{SH} 3$ deletions on the functional activities of wild-type and transforming variants of c-Src. Mol. Cell. Biol. 12: 1835-1845.

Shau, H., L.H. Butterfield, R. Chiu, and A. Kim. 1994. Cloning and sequence analysis of candidate human natural killerenhancing factor genes. Immunogenetics 40: 129-134.

Shi, Y., K. Alin, and S.P. Goff. 1995. Abl-interactor-1, a novel $\mathrm{SH} 3$ protein binding to the carboxy-terminal portion of the Abl protein, suppresses v-abl transforming activity. Genes \& Dev. 9: 2583-2597.

Sicheri, F., I. M oarefi, and J. Kuriyan. 1997. Crystal structure of the Src family tyrosine kinase Hck. Nature 385: 602-609.

Sies, H. 1993. Strategies of antioxidant defense. Eur. J. Biochem. 215: 213-219.

Tybulewicz, V.L.J., C.E. Crawford, P.K. Jackson, and R.C. Mulligan. 1991. Neonatal lethality and Iymphopenia in mice with a homozygous disruption of the c-abl protooncogene. Cell 65: 1153-1164.

Van Etten, R.A., P. Jackson, and D. Baltimore. 1989. The mouse 
type IV c-abl gene product is a nuclear protein, and activation of transforming ability is associated with cytoplasmic localization. Cell 58: 669-678.

Van Etten, R.A., P.K. Jackson, D. Baltimore, M.C. Sanders, P.T. M atsudaira, and P.A. Janmey. 1994. The C-terminus of the $\mathrm{C}-\mathrm{A} \mathrm{bl}$ tyrosine kinase contains distinct $\mathrm{F}$ - and $\mathrm{G}$-actin binding domains with bundling activity. J. Cell Biol. 124: 325340.

Van Etten, R.A., J. Debnath, H. Zhou, and J.M. Casasnovas. 1995. Introduction of a loss-of-function point mutation from the $\mathrm{SH} 3$ region of the Caenorhabditis elegans sem- 5 gene activates the transforming ability of c-abl in vivo and abolishes binding of proline-rich ligands in vitro. Oncogene 10: 1977-1988.

Wang, J.Y.J., F. Ledley, S. Goff, R. Lee, Y. Groner, and D. Baltimore. 1984. The mouse c-abl locus: Molecular cloning and characterization. Cell 36: 349-356.

Welch, P.J. and J.Y.J. Wang. 1995. Disruption of retinoblastoma protein function by coexpression of its $C$ pocket fragment. Genes \& Dev. 9: 31-46.

Wen, S.-T., P.K. Jackson, and R.A. Van Etten. 1996. The cytostatic function of c-Abl is controlled by multiple nuclear localization signals, and requires the p53 and $\mathrm{Rb}$ tumor suppressor gene products. EMBO J. 15: 1583-1595.

Wilson, I.A., H.L. Niman, R.A. Houghten, A.R. Cherenson, M.L. Connolly, and R.A. Lerner. 1984. The structure of an antigenic determinant in a protein. Cell 37: 767-778.

Witte, O.N., A. Ponticelli, A. Gifford, D. Baltimore, N. Rosenberg, and J. Elder. 1981. Phosphorylation of the abel son murine leukemia virus transforming protein. J. Virol. 39: 870878.

Xu, W., S.C. Harrison, and M.J. Eck. 1997. Three-dimensional structure of the tyrosine kinase c-Src. Nature 385: 595-602.

Yamamoto, T., Y. Matsui, S. Natori, and M. Obinata. 1989. Cloning of a housekeeping-type gene (MER5) preferentially expressed in murine erythroleukemia cells. Gene 80: 337343.

Yu, H., J.K. Chen, S. Feng, D.C. Dal garno, A.W. Brauer, and S.L. Schreiber. 1994. Structural basis for the binding of prolinerich peptides to SH 3 domains. Cell 76: 933-945.

Yuan, Z.-M., Y. Huang, Y. Whang, C. Sawyers, R. Weichselbaum, S. Kharbanda, and D. Kufe. 1996. Role for c-A bl tyrosine kinase in growth arrest response to DNA damage. Nature 382: 272-274.

Yuan, Z.M., Y. Huang, T. Ishiko, S. Kharbanda, R. Weichselbaum, and D. Kufe. 1997. Regulation of DNA damage-induced apoptosis by the c-Abl tyrosine kinase. Proc. Natl. Acad. Sci. 94: 1437-1440.

Zervos, A.S., J. Gyuris, and R. Brent. 1993. Mxi1, a protein that specifically interacts with $\mathrm{M}$ ax to bind Myc-Max recognition sites. Cell 72: 223-232.

Zhu, J. and S.K. Shore. 1996. c-Abl tyrosine kinase activity is regulated by association with a novel $\mathrm{SH}$ 3-domain-binding protein. Mol. Cell. Biol. 16: 7054-7062. 


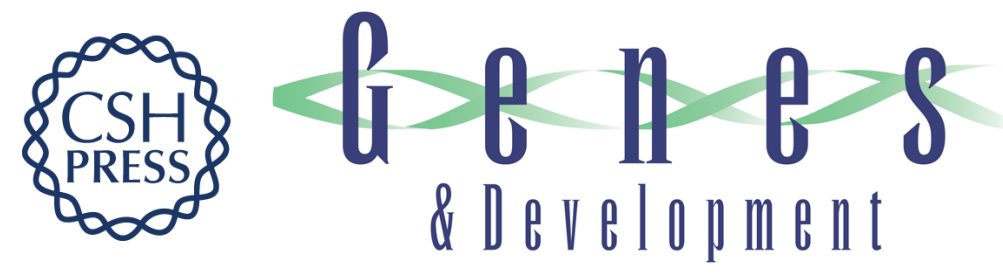

\section{The PAG gene product, a stress-induced protein with antioxidant properties, is an Abl SH3-binding protein and a physiological inhibitor of c-Abl tyrosine kinase activity}

Shih-Te Wen and Richard A. Van Etten

Genes Dev. 1997, 11:

Access the most recent version at doi:10.1101/gad.11.19.2456

$\begin{array}{ll}\text { References } & \begin{array}{l}\text { This article cites } 73 \text { articles, } 33 \text { of which can be accessed free at: } \\ \text { http://genesdev.cshlp.org/content/11/19/2456.full.html\#ref-list-1 }\end{array}\end{array}$

License

Email Alerting Receive free email alerts when new articles cite this article - sign up in the box at the top Service right corner of the article or click here.

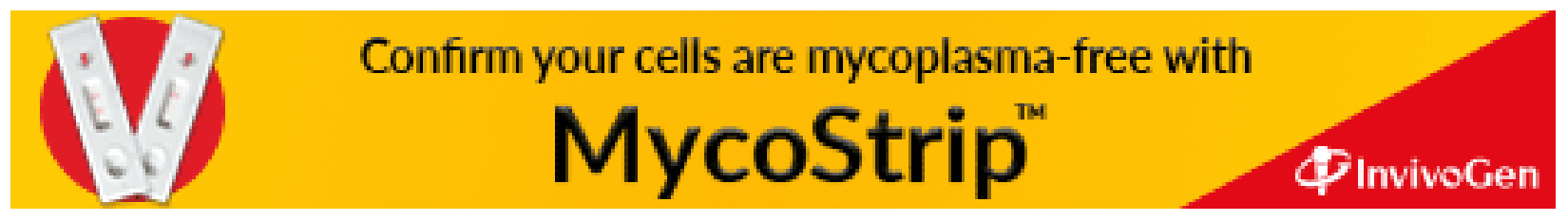

